\title{
SUPERVISI AKADEMIK KEPALA SEKOLAH UNTUK MENINGKATKAN PROSES PEMBELAJARAN
}

\author{
RIRI SULIYARTI \\ 16002061 \\ ririsuliyarti@gmail.com
}

\begin{abstract}
Supervisi akademik yang dilakukan oleh kepala sekolah sangat penting bagi guru untuk meningkatkan proses pembelajaran. Supervisi akademik yang dlakukan oleh kepala sekolah sebagi supervisor ini meliputi supervisi dalam perencanaan pembelajaran, pelaksanaan pembelajaran, dan evaluasi atau penilaian pembelajaran. Pelaksanaan supervisi akademik ini bukan hanya berdampak pada cara mengajar guru, namun juga memiliki andil besar dalam peningkatan prestasi peserta didik. Melalui supervisi akademik, kepala sekolah dapat menjalankan salah satu tugas dan fungsinya sebagai supervisor dalam bidang supervisi pendidikan.
\end{abstract}

Keywords : supervisi akademik; kepala sekola;, supervisor; pembelajaran.

\section{PENDAHULUAN}

Penyelenggaraan dan pengelolaan pendidikan keberhasilannya ditentukan oleh kemampuan kepala sekolah dalam mengelola semua sumber daya yang ada di sekolah. Kepala sekolah merupakan salah satu komponen pendidikan yang paling berperan dalam meningkatkan kualitas pendidikan. (Mulyasa, 2004) Artinya, yang menjadi penentu keberhasilan suatu sekolah terletak pada kemampuan kepala sekolah dalam melaksanakan tugas-tugasnya. Tugas utama kepala sekolah sebagai pemimpin sekolah adalah menciptakan situasi belajar mengajar yang kondusif sehingga para guru dan siswa dapat melaksanakan kegiatan belajar mengajar dengan baik di lingkungan sekolahnya.
Kepala sekolah dituntut memiliki kompetensi dalam membina guru-guru. Dalam Peraturan Menteri Pendidikan Nasional No. 13 Tahun 2007 tentang Standar Kepala Sekolah/Madrasah, ditegaskan bahwa seorang kepala sekolah/madrasah harus memiliki kompetensi kepribadian, manajerial, kewirausahaan, supervisi, dan sosial. Semua kompetensi tersebut mutlak harus dimiliki oleh kepala sekolah agar mampu mewujudkan pembelajaran yang bermutu dalam rangka mencapai pendidikan yang berkualitas di sekolah. Kepala sekolah lebih dekat dengan sekolah bahkan melekat pada kehidupan sekolah yang lebih banyak mengarahkan perhatiannya pada supervisi pengajaran/akademik. (Arikunto, 2004)

Program yang dapat diselenggarakan untuk meningkatkan mutu pembelajaran 
adalah supervisi. Kepala sekolah sebagai pemimpin pendidikan di sekolah mempunyai tugas di bidang supervisi. Tugas di bidang supervisi merupakan tugas-tugas kepala sekolah yang berkaitan dengan pembinaan guru untuk perbaikan pengajaran. (Departemen Pendidikan Nasional, 2007) Supervisi adalah layanan bantuan profesional kepada guru guna meningkatkan kemampuan dalam melaksanakan proses pembelajaran harus dilaksanakan secara efektif dan efisien. (Bafadal, 2000) Seharusnya supervisi dilakukan dalam rangka menjamin pembelajaran yang berkualitas, keberhasilan pelaksanaan supervise diukur dari peningkatan prestasi belajar siswa. (Sabandi, 2013)

Salah satu kegiatan supervisi yang dapat dilakukan oleh kepala sekolah untuk meningkatkan proses pembelajaran adalah supervisi akademik. Supervisi akademik adalah serangkaian kegiatan membantu guru mengembangkan kemampuannya mengelola proses pembelajaran demi pencapaian tujuan pembelajaran. (Prasojo, 2011) Sasaran dari supervisi akademik adalah guru dalam proses pembelajaran, yang terdiri dari materi pokok dalam proses pembelajaran, penyusunan silabus dan RPP, pemilihan strategi/ metode/ teknik pembelajaran, penggunaan media dan teknologi informasi dalam pembelajaran, menilai proses pembelajaran dan hasil pmbelajaran. (Prasojo, 2011)

Pelaksanaannya supervisi dalam lembaga pendidikan masih menemui berbagai kendala baik itu dalam teknik penyampaian maupun intensitas pelaksanaan supervisi yang dilakukan belum ditetapkan dengan baik sehingga kepala sekolah masih insidental mengadakan pembinaan dan pelatihan kepada guru dalam proses pembelajaran. Dalam kenyataannya kepala sekolah belum dapat melaksanakan supervisi dengan baik dengan alasan beban kerja kepala sekolah yang terlalu berat serta latar belakang pendidikan yang kurang sesuai dengan bidang studi yang disupervisi. (Arikunto, 2004) Sehingga tujuan untuk membina dan membimbing guru masih belum sempurna serta guru kurang memahami makna dari pentingnya supervisi yang dilakukan oleh kepala sekolah.

Proses pembelajaran merupakan kegiatan yang sangat penting dalam penyelenggaraan pendidikan di sekolah. Proses pembelajaran yang baik akan mampu meningkatkan prestasi belajar peserta didik serta meningkatkan kualitas lulusan sekolah. Dalam upaya mencapai proses pembelajaran yang baik maka guru memerlukan bantuan dari kepala sekolah dalam melaksanakan tugas mengajarnya. Bantuan pada proses pembelajaran ini lebih dikenal dengan istilah supervisi akademik. Supervisi akademik oleh kepala sekolah meliputi supervisi akademik pada perencanaan pembelajaran, supervisi akademik pada pelaksanaan pembelajaran, dan supervisi akademik pada evaluasi pembelajaran. Indicator pelaksanaan supervisi pembelajaran meliputi perencanaan supervise pembelajaran, pelaksanaan supervise pembelajaran, dan evaluasi supervise pembelajaran. (Muhammad, Hadiyanto, \& Rifma, 2000)

Pentingnya supervisi akademik juga terkait dengan hal yang disampaikan Supriano saat membuka program Innovative Schools Programme (ISP) di Jakarta, Sabtu (9/2/2019), bahwa fokus pada saat ini yaitu peningkatan proses pembelajaran, dan bagaimana meningkatkan kompetensi pembelajaran di kelas. Bukan prosesnya bukan konten atau materi pembelajarannya. Direktur Jenderal Guru dan Tenaga Kependidikan Kementerian Pendidikan dan Kebudayaan, Supriano mengatakan proses pembelajaran di kelas harus dibenahi agar bisa menciptakan kelas yang menyenangkan. Hal ini selain dibantu melalui MGMP, tentu juga dapat dilaksanakan 
dengan adanya bantuan atau supervisi akademik oleh kepala sekolah.

Oleh sebab itu, penulis akan menulis mengenai supervisi akademik kepala sekolah dalam meningkatkan proses pembelajaran di sekolah yang dibagi meliputi supervisi akademik pada perencanaan pembelajaran, supervisi akademik pada pelaksanaan pembelajaran, dan supervisi akademik pada evaluasi pembelajaran.

\section{PEMBAHASAN}

\section{Supervisi Akademik pada Perencanaan Pembelajaran}

Perencanaan adalah menetapkan pekerjaan yang harus dilaksanakan oleh kelompok atau individu untuk mencapai tujuan yang digariskan. (Ambarita, 2006) Lebih lanjut. perencanaan pembelajaran adalah salah satu fungsi awal bagi aktivitas manajemen dalam mencapai tujuan secara efektif dan efisie. (Syafaruddin dan Irawan, 2005)

Beberapa faktor yang menjadi
perhatian untuk membuat perencanaan pembelajaran yaitu: isi pembelajaran, alat-alat pembelajaran, stategi perencanaan, perilaku guru, struktur pelajaran, peningkatan pembelajaran, peserta didik, waktu yang diperlukan dalam belajar, dan tempat belajar. (Ambarita, 2006) Dalam Permendiknas nomor 41 tahun 2007 dijelaskan bahwa perencanaan pembelajaran meliputi penyusunan silabus dan rencana pelaksanaan pembelajaran (RPP) yang memuat sekurangkurangnya tujuan pembelajaran, materi bahan ajar, sumber belajar, metode pembelajaran, dan penilaian hasil belajar.

\section{Tujuan Pembelajaran}

Menurut Permendiknas nomor 41 tahun 2007, tujuan pembelajaran menggambarkan proses dan hasil belajar yang diharapkan dicapai oleh peserta didik sesuai dengan kompetensi dasar. Sementara itu, tujuan pembelajaran merupakan perilaku yang hendak dicapai atau yang dapat dikerjakan siswa pada kondisi dan tingkat kompetensi tertentu. Artinya, tujuan pembelajaran merupakan perilaku yang dapat dikerjakan dan dicapai siswa pada tingkat kompetensi tertentu. (Uno, 2008)

\section{Materi Pembelajaran}

Dalam Permendiknas nomor 41 tahun 2007, dijelaskan bahwa materi ajar memuat fakta, konsep, prinsip dan prosedur yang relevan, dan ditulis dalam bentuk butir-butir sesuai dengan rumusan indikator pencapaian kompetensi. Materi pembelajaran pada hakikatnya berisi butir-butir bahan pembelajaran pokok yang dibutuhkan peserta didik untuk mencapai suatu kompetensi dasar. Berdasarkan uraian tersebut, materi pembelajaran berisi butir-butir bahan pembelajaran pokok yang dibutuhkan peserta didik meliputi fakta, konsep, prinsip, dan prosedur. (Trianto, 2011)

\section{Sumber Belajar}

Dalam Permendiknas nomor 41 tahun 2007, dijelaskan bahwa penentuan sumber belajar didasarkan pada standar kompetensi dan kompetensi dasar, serta materi ajar, kegiatan pembelajaran, dan indikator pencapaian kompetensi. Sumber belajar dapat dirumuskan sebagai segala sesuatu yang dapat memberikan kemudahan belajar, sehingga diperoleh sejumlah informasi. (Mulyasa, 2008) Dengan demikian sumber belajar merupakan segala sesuatu yang bisa memberikan kemudahan belajar siswa untuk mencapai standar kompetensi dan kompetensi dasar.

\section{Metode Pembelajaran}

Dalam Permendiknas nomor 41 tahun 2007, dijelaskan bahwa metode pembelajaran 
digunakan oleh guru untuk mewujudkan suasana belajar dan proses pembelajaran agar peserta didik mencapai kompetensi dasar. Lebih lanjut, metode pembelajaran merupakan cara-cara yang berbeda untuk mencapai hasil pembelajaran yang berbeda di bawah kondisi yang berbeda. (Uno, 2008) Jadi, metode pembelajaran merupakan cara yang digunakan guru untuk mewujudkan proses pembelajaran yang baik agar peserta didik dapat mencapai kompetensi dasar.

\section{Kegiatan Pembelajaran}

Dalam Permendiknas nomor 41 tahun 2007, dijelaskan bahwa kegiatan pembelajaran meliputi kegiatan pendahuluan, kegiatan inti, dan kegiatan penutup.

\section{Penilaian Hasil Belajar}

Dalam Permendiknas nomor 41 tahun 2007, dijelaskan bahwa prosedur dan instrumen penilaian proses dan hasil belajar disesuaikan dengan indikator pencapaian kompetensi dan mengacu kepada standar penilaian. Penilaian bermaksud untuk mengetahui kelebihan dan kelemahan, sehingga dapat ditindak lanjuti menuju perbaikan dimasa yang akan datang. (Rusman, 2012) Dengan demikian, penilaian hasil belajar merupakan suatu cara untuk mengetahui kelebihan dan kelemahan sehingga dapat diperbaiki.

Dari uraian di atas, dapat disimpulkan bahwa perencanaan pembelajaran adalah suatu kegiatan yang dilakukan oleh guru yaitu menetapkan rangkaian tindakan kedepan untuk menjelaskan gambaran dan langkahlangkah proses pembelajaran yang akan datang dengan tujuan agar pelaksanakaan pembelajaran berjalan dengan baik, efektif, dan efisien. Perencanaan pembelajaran mencakup kegiatan-kegiatan merencanakan tujuan pembelajaran, materi pembelajaran, sumber belajar, metode pembelajaran, serta kegiatan pembelajaran yang dilakukan oleh guru.

Dengan demikian, supervisi akademik oleh kepala sekolah pada perencanaan pembelajaran dapat dilakukan dengan memberikan bimbingan dalam merumuskan tujuan pembelajaran, arahan dalam memilih materi pembelajaran, bimbingan dalam mengorganisir materi pembelajaran, arahan dalam memilih metode pembelajaran, arahan dalam memilih sumber belajar/media pembelajaran, dan bimbingan dalam menskenario/kegiatan pembelajaran.

\section{Supervisi Akademik pada Pelaksanaan Pembelajaran}

Pelaksanaan pembelajaran merupakan inti dari kegiatan pendidikan di sekolah. Pelaksanaan pembelajaran merupakan terjadinya interaksi guru dengan siswa dalam rangka menyampaikan bahan pelajaran kepada siswa untuk mencapai tujuan pengajaran. (Suryosubroto, 2002) Sejalan dengan pendapat tersebut, pelaksanaan pembelajaran merupakan suatu proses penyelenggaraan interaksi peserta didik dengan pendidik dan sumber belajar pada suatu lingkungan belajar. (Majid, 2006)

Pelaksanaan proses pembelajaran, meliputi kegiatan membuka pembelajaran, melaksanakan inti proses belajar mengajar, dan menutup pembelajaran. (Suryosubroto, 2002) Lebih lanjut, pelaksanaan pembelajaran diurai meliputi: (a) kegiatan pendahuluan: menyiapkan peserta didik, mengajukan pertanyaan, menjelaskan tujuan, menyampaikan cakupan materi, (b) kegiatan inti: proses pembelajaran untuk mencapai kompetensi dasar yang dilakukan secara interaktif, inspiratif, menyenangkan, menantang, memotivasi, serta memberikan ruangan yang cukup bagi prakarsa, kreativitas, dan kemandirian sesuai bakat dan minat, (c) Kegiatan penutup: bersama-sama membuat kesimpulan pelajaran, melakukan refleksi, 
memberikan umpan balik, merencanakan tindak lanjut, menyampaikan rencana pembelajaran pada pertemuan berikutnya. (Rusman, 2012) Komponen yang termasuk dalam pelaksanaan pembelajaran menurut Permendiknas Nomor 41 tahun 2007 tentang standar proses, meliputi: pendahuluan, kegiatan inti, dan penutup.

Jadi, dapat disimpulkan bahwa bahwa pelaksanaan pembelajaran merupakan suatu proses terjadinya interaksi guru dengan siswa dalam rangka menyampaikan bahan pelajaran kepada siswa pada suatu lingkungan belajar. Kegiatan-kegiatan dalam pelaksanaan pembelajaran yaitu kegiatan membuka pembelajaran, kegiatan inti pembelajaran, dan kegiatan menutup pembelajaran

Dengan demikian, supervisi
akademik oleh kepala sekolah pada
pelaksanaan pembelajaran dapat dilakukan dengan memberikan contoh dalam membuka pembelajaran, memberikan contoh dalam menyajikan materi pembelajaran, arahan dalam menggunakan metode pembelajaran, bimbingan dalam memanfaatkan media pembelajaran, bimbingan dalam menggunakan bahasa komunikatif, bantuan dalam memotivasi siswa, bimbingan dalam mengorganisasi kegiatan pembelajaran, memberikan contoh dalam berinteraksi dengan siswa, memberikan contoh dalam menyimpulkan pembelajaran, memberikan contoh dalam pemberian umpan balik pada siswa, arahan dalam menggunakan waktu yang efektif, dan memberikan contoh dalam menutup kegiatan pembelajaran.

\section{Supervisi Akademik pada Evaluasi Pembelajaran}

Evaluasi atau penilaian hasil belajar bertujuan untuk melihat kemajuan belajar siswa dalam hal penguasaan materi pelajaran yang telah dipelajari. Penilaian atau evaluasi harus digunakan sebagai proses untuk mengukur dan menentukan tingkat ketercapaian kompetensi dan sekaligus untuk mengukur efektifitas proses pembelajaran. (Majid, 2006) Dengan demikian, evaluasi atau penilaian pembelajaran sangat diperlukan dalam proses pembelajaran.

UU RI nomor 20 tahun $2003 \mathrm{Bab}$ XVI pasal 57 ayat 1 dan pasal 58 ayat 8 menyatakan bahwa, "Evaluasi dilakukan dalam rangka pengendalian mutu pendidikan secara nasional sebagai bentuk akuntabilitas penyelenggaraan pendidikan kepada pihakpihak yang berkepentingan. Evaluasi belajar peserta didik dilakukan oleh pendidik untuk memantau proses, kemajuan, dan perbaikan hasil belajar secara berkesinambungan". Dengan demikian, evaluasi terhadap hasil belajar yang telah menjadi standar keberhasilan perlu dilakukan oleh guru. Evaluasi terhadap hasil belajar bertujuan untuk mengetahui ketuntasan siswa dalam menguasai kompetensi dasar. (Majid, 2006) Dari hasil evaluasi tersebut dapat diketahui kompetensi dasar, materi, atau indikator yang belum mencapai ketuntasan.

Penilaian pembelajaran mempunyai manfaat yang sangat besar, sebab dengan adanya evaluasi atau penilaian maka perkembangan kecerdasan siswa selama mengikuti proses pembelajaran dapat diukur. Dalam Permendiknas RI nomor 20 tahun 2007, dijelaskan bahwa penilaian hasil belajar bertujuan untuk memantau proses dan kemajuan belajar peserta didik serta untuk meningkatkan efektivitas kegiatan pembelajaran.

Penilaian tersebut meliputi kegiatan sebagai berikut: (a) Menginformasikan silabus mata pelajaran yang di dalamnya memuat rancangan dan kriteria penilaian pada awal semester; (b) Mengembangkan indikator pencapaian KD dan memilih teknik penilaian yang sesuai pada saat menyusun silabus mata pelajaran; c) Mengembangkan instrumen dan pedoman penilaian sesuai dengan bentuk dan 
teknik penilaian yang dipilih; (d) Melaksanakan tes, pengamatan, penugasan, dan atau bentuk lain yang diperlukan; (e) Mengolah hasil penilaian untuk mengetahui kemajuan hasil belajar dan kesulitan belajar peserta didik; (f) Mengembalikan hasil pemeriksaan pekerjaan peserta didik disertai balikan/komentar yang mendidik; (g) Memanfaatkan hasil penilaian untuk perbaikan pembelajaran; (h) Melaporkan hasil penilaian mata pelajaran pada setiap akhir semester kepada pimpinan satuan pendidikan dalam bentuk satu nilai prestasi belajar peserta didik disertai deskripsi singkat sebagai cerminan kompetensi utuh; (i) Melaporkan hasil penilaian akhlak kepada guru Pendidikan Agama dan hasil penilaian kepribadian kepada guru Pendidikan Kewarganegaraan sebagai informasi untuk menentukan nilai akhir semester semester akhlak dan kepribadian peserta didik dengan kategori sangat baik, baik, atau kurang baik.

Jadi, dapat diambil kesimpulan bahwa evaluasi atau penilaian pembelajaran adalah suatu upaya pengukuran dan penentuan tingkat ketercapaian tujuan pembelajaran meliputi hal-hal yang dimiliki oleh siswa sesuai materi pembelajaran dari pendidik. Evaluasi belajar dilakukan oleh pendidik untuk memantau proses, kemajuan, dan perbaikan hasil belajar siswa secara berkesinambungan. Kegiatan-kegiatan dalam evaluasi pembelajaran meliputi: penyusunan perangkat penilaian, pembuatan soal-soal pembelajaran, penggunaan strategi dan metode penilaian, memeriksa jawaban, mengolah dan menganalisis hasil penilaian, dan pemanfaatan hasil penilaian pembelajaran siswa.

Dengan demikian, supervisi akademik oleh kepala sekolah pada evaluasi pembelajaran dapat dilakukan dengan memberikan bimbingan dalam menyusun perangkat penilaian pembelajaran, bimbingan dalam membuat soal-soal pembelajaran, arahan dalam menggunakan strategi dan metode penilaian pembelajaran, arahan dalam memeriksa jawaban penilaian belajar siswa, bimbingan dalam mengolah dan menganalisis hasil penilaian belajar siswa, dan bimbingan dalam memanfaatkan hasil penilaian belajar siswa.

\section{SIMPULAN DAN SARAN}

Supervisi akademik sangat penting untuk meningkatkan proses pembelajaran, baik itu pada perencanaan pembelajaran, pelaksanaan maupun evaluasi atau penilaian pembelajaran, karena dapat meningkatkan prestasi peserta didik dalam proses pembelajaran Diharapkan kepala sekolah dapat menjalankan salah satu fungsinya sebagai supervisor.

\section{DAFTAR RUJUKAN}

Ambarita, A. (2006). Manajemen Pembelajaran. Jakarta: Rineka Cipta.

Arikunto, S. (2004). Dasar-dasar Supervisi. Jakarta: Rineka Cipta.

Bafadal, I. (2000). Supervisi Pengajaran. Jakarta: Bumi Aksara.

Departemen Pendidikan Nasional. (2007). Pendidikan dan Pelatihan: Supervisi Akademik dalam Peningkatan Profesionalisme Guru. Jakarta: Depdiknas.

Majid, A. (2006). Perencanaan Pembelajaran. Bandung: Remaja Rosdakarya.

Muhammad, A., Hadiyanto, \& Rifma. (2000). Bahan Ajar Supervisi Pembelajaran. Padang: FIP UNP.

Mulyasa, E. (2004). Menjadi Kepala Sekolah Profesional. Bandung: Remaja Rosdakarya.

Mulyasa, E. (2008). Menjadi Guru Profesional Menciptakan Pembelajaran 
Kreatif dan Menyenangkan. Bandung:

Remaja Rosdakarya.

Prasojo, L. D. dan S. (2011). Supervisi

Pendidikan. Yogyakarta: Gava Media.

Rusman. (2012). Model-model Pembelajaran: Mengembangkan Profesionalisme Guru. Jakarta: Rajawali Pers.

Sabandi, A. (2013). Supervisi Pendidikan Untuk Pengembangan Profesionalitas Guru Berkelanjutan. Jurnal Ilmiah Ilmu Pendidikan, XIII(2), 1-9.

Suryosubroto, B. (2002). Proses Belajar Mengajar di Sekolah. Jakarta: Rineka Cipta.

Syafaruddin dan Irawan. (2005). Manajemen Pembelajaran. Jakarta: Ciputat Press.

Trianto. (2011). Mendesain Model Pembelajaran Inovatif-Progresif. Jakarta: Kencana.

Uno, H. B. (2008). Perencanaan

Pembelajaran. Jakarta: Bumi Aksara. 


\section{LAMPIRAN}

Kemendikbud: Untuk Masalah Konten, Guru-Guru Indonesia Tidak Perlu Diragukan
Lagi

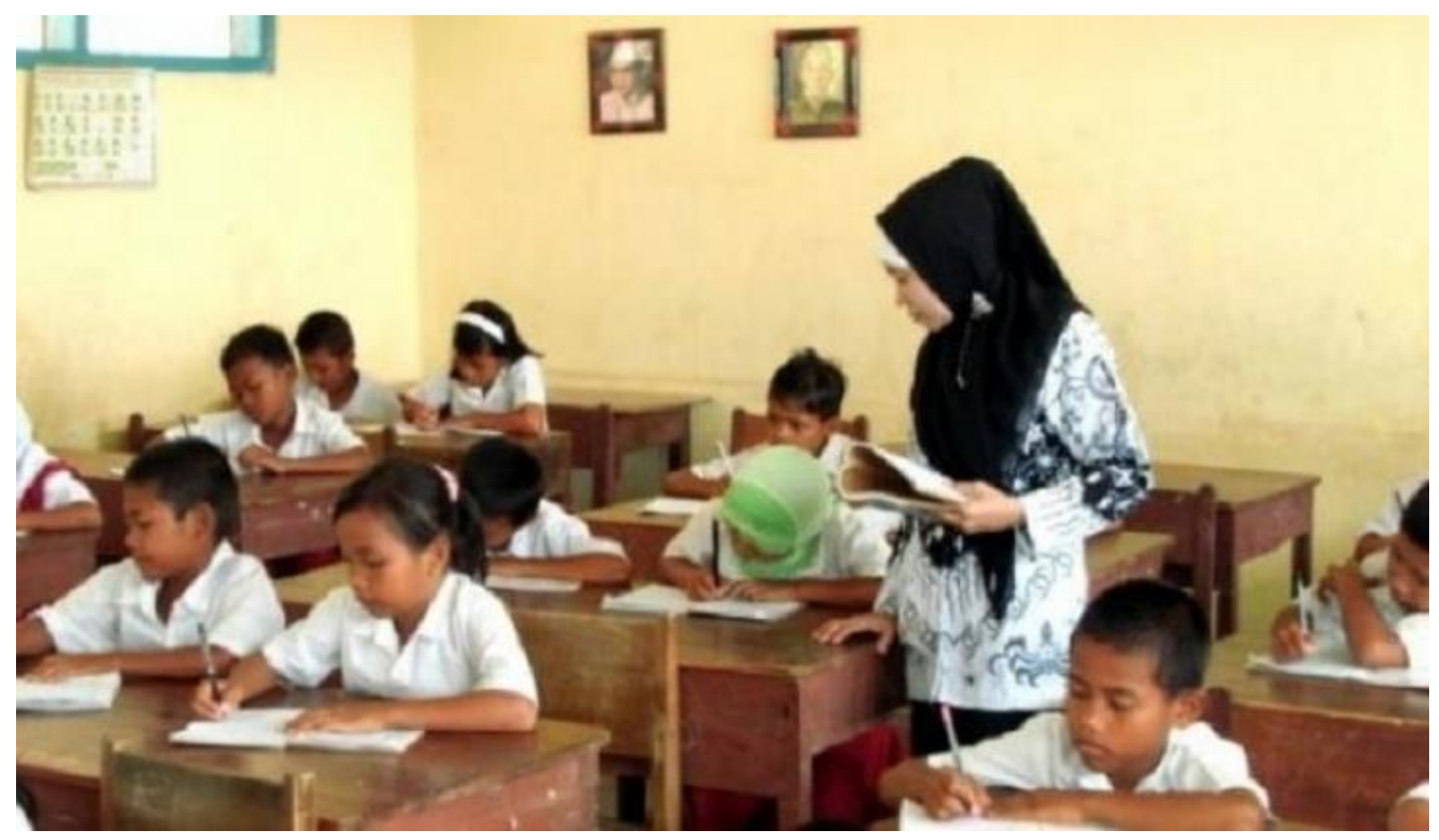

\section{Warta Ekonomi.co.id, Jakarta -}

Direktur Jenderal Guru dan Tenaga Kependidikan Kementerian Pendidikan dan Kebudayaan, Supriano mengatakan proses pembelajaran di kelas harus dibenahi agar bisa menciptakan kelas yang menyenangkan.

"Saat ini kita fokus pada peningkatan proses pembelajaran, bagaimana meningkatkan kompetensi pembelajaran di kelas. Jadi prosesnya bukan konten atau materi pembelajarannya," ujar Supriano saat membuka program Innovative Schools Programme (ISP) di Jakarta, Sabtu (9/2/2019).

Menurut Dirjen GTK, untuk masalah konten atau materi pembelajaran guru-guru Indonesia tidak perlu diragukan lagi.

Tetapi yang masih menjadi kendala adalah bagaimana prosesnya sehingga menjadikan kelas menyenangkan, siswa berpatisipasi aktif, dan siswa mampu mengungkapkan keinginannya.

Perbaikan proses pembelajaran tersebut dilakukan melalui Musyawarah Guru Mata Pelajaran (MGMP) dan juga sistem zonasi. Untuk persentase peningkatan proses pembelajaran terdiri dari $70 \%$ pedagogik dan $30 \%$ konten atau materi pelajaran. 
"Jika proses pembelajaran sudah baik, maka akan menghasilkan mutu yang baik pula," kata dia lagi.

Supriano menyambut baik ISP yang diinisiasi sejumlah sekolah satuan pendidikan kerja sama yakni Jakarta Intercultural School (JIS) bersama Yayasan Emmanuel, dan Mentari Intercultural School Jakarta dan lainnya.

Dengan metode modern, para pengajar dari sekolah SPK berbagi pengetahuan internasional mereka tentang cara dan praktik mengajar yang menarik sehingga dapat menciptakan suasana pembelajaran yang menyenangkan.

Sumber : https://www.wartaekonomi.co.id/read214970/kemendikbud-untuk-masalah-kontenguru-guru-indonesia-tidak-perlu-diragukan-lagi.html 